\title{
New Perspectives On The Use Of LIFO And Firm Size
}

John Kostolansky, Loyola University Chicago, USA

Ethan Polnaszek, Loyola University Chicago, USA

\begin{abstract}
Recent calls to repeal the use of LIFO raise questions about the number of firms that will be impacted, the extent of that impact, as well as the demographics of the impacted firms. The present study assesses the population of publicly-traded companies to determine the frequency of usage of LIFO, the dollar impact of using LIFO, and the connection between firm size and the use of LIFO. This study finds that the tax impact of repealing LIFO may be more manageable than has been reported in the financial press. In addition, this study documents the connection between absolute and relative firm size and the use of LIFO.
\end{abstract}

Keywords: Last-In, First Out Inventory Method; LIFO; LIFO Repeal; Firm Size

\section{INTRODUCTION}

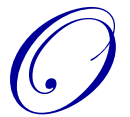

n September 18, 2002, the Financial Accounting Standards Board and the International Accounting Standards Board affirmed their mutual commitment to "make their existing financial reporting standards fully compatible as soon as is practicable" (FASB). Because international financial reporting standards [IFRS] do not allow the use of the LIFO inventory method, the agreement marked a formal movement that could eliminate the use of LIFO in the U.S. Concurrent global economic woes have challenged most countries to cut spending and find new sources of revenue. Consequently, the repeal of the LIFO tax method has been proposed in the past five U.S. budgets. Most recently, the FY 2014 budget projected that a repeal of LIFO would reduce the U.S. deficit by $\$ 80.8$ billion over the next 10 years.

Not surprisingly, proponents on both sides of the LIFO issue have been vocal to make their respective case. On one side, LIFO has been characterized as a "massive tax holiday" (Kleinbard et al, 2006). On the other side, it has been reported that "manufacturers, wholesalers, retailers and oil companies would be especially hard hit" as a result of repealing the LIFO tax method (Pear, 2011). The LIFO Coalition asserts that LIFO "is not used exclusively or even primarily by 'big oil' or other large corporations but by hundreds of thousands of smaller companies [emphasis added]" (LIFO Coalition, 2010).

Two previous studies have estimated the impact of LIFO on large firms. Mulford and Comiskey (2008) assessed the impact of eliminating LIFO on 30 large firms, while Kostolansky (2007) examined the impact on income and assets of the Fortune 500 firms. In addition, Vitale (2010) estimated the impact of repealing LIFO on various industries for 2007. There is, however, a lack of information about the relative impact on smaller firms. The purpose of this study is to report on the use of LIFO over time, to assess how a repeal of the LIFO tax method will affect firms of all sizes, and to shed light on the connection between firm size and the use of LIFO. Firm size will be assessed in both absolute and relative terms.

\section{RESEARCH METHOD}

For this study, we first obtained LIFO-company data from the Compustat North America database for the period 1992 through 2011 in order to assess the history and trend of LIFO usage over an extended period. We included companies with either a positive or negative LIFO reserve for any year during the period. This search produced a total of 553 firms that reported a LIFO reserve in at least one year during the twenty-year period, and an average number of LIFO firms of 350 per year. 
Next we focused on the firms reporting a LIFO reserve during the five-year period 2007 to 2011. Using the data for the 20-year history, we merged the data for the 322 firms using LIFO in 2007 and the 300 firms using LIFO in 2011. We removed firms that discontinued reporting a LIFO reserve during the period and we incorporated firms that initiated using LIFO reserve between 2007 and 2011 and reported at least three years of LIFO data. Following this approach, our final group consisted of 297 LIFO firms.

In order to assess the impact of repealing LIFO, we compared the amount of taxes that the firms would have to pay in relation to various measures of the firm's ability to pay. We chose the following measures of ability to pay: Cash and Short-term Investments, Working Capital, and Cash Flow from Operations. Since these measures can fluctuate considerably from year to year, we judged that the five-year average for each these metrics would be a more reliable measure of ability to pay taxes. We estimated the amount of taxes that would have to be paid as $35 \%$ of the 2011 LIFO reserve. We then compared each of the five-year averages to the estimated amount of taxes and represented that result as a percentage.

Finally, to shed light on the connection of firm size to the use of LIFO, we arrayed the population of 6,458 firms for 2011 from the Compustat Global North America Database. Since two groups of firms in this list would generally not be able to use LIFO, we decided to remove them from consideration. First we removed 982 firms that were incorporated outside the United States since the use LIFO is generally unavailable in other countries. Four of these firms did, in fact, report a LIFO reserve presumably because they reported under U.S. GAAP. Nonetheless, we believe it makes sense to remove the foreign firms from our analysis to avoid skewing the results. Second, we removed 1,270 firms from the financial services industry (SIC codes 6020 through 6799) since such firms would not carry inventory. In fact, none of these firms reported a LIFO reserve. This left us with 4,206 firms for analysis.

To explore the connection between LIFO usage and absolute firm size, we divided this remaining group into thirds based on total assets as a proxy for small, medium, and large firms. Then we simply tabulated the number of LIFO firms in each group.

To delve further into this issue, we explored the relative size of LIFO firms in various industries. Again using total assets as our measure of firm size, we calculated both the average and median amount of assets for LIFO and non-LIFO firms in select industries. Finally, since many industries contained only one LIFO firm, we noted that this provided another perspective on relative firm size, namely the percentile size ranking of LIFO firms in those industries.

\section{RESULTS}

From 1992 to 2011, the number of publicly-traded firms using LIFO was relatively constant, averaging 350 firms per year. This number has ranged from the 1994 and 1995 peak of 384 firms to a low of 300 firms, which interestingly enough, occurred in both 1992 and 2011. Given there were 5,400 publicly-held companies in 2008 (Weild, 2009), LIFO is clearly not used by most firms.

The total LIFO reserve balances over this period remained fairly steady from 1992 to 2003, averaging nearly $\$ 33$ billion. From 2003 onward, LIFO reserve balances increased dramatically to $\$ 105.9$ billion in 2011 . The repeal of the LIFO tax method would therefore generate an estimated $\$ 37$ billion in future tax revenues from the companies in our study (35\% tax rate x $\$ 105.9$ ). This is considerably less than the $\$ 80.8$ billion of estimated deficit reduction in the U.S. budget for FY2014. The difference presumably is related to private companies using LIFO.

As mentioned earlier, we dropped from our study those companies that ceased reporting a LIFO reserve during the years 2007-2011. Nonetheless we examined the Annual Report 10-K for those firms and determined that 38 of those companies voluntarily switched from LIFO to another method. Thus, over $10 \%$ of the LIFO companies in the Compustat database voluntary stopped using LIFO during the five-year period 2007-2011. The majority of these companies chose to use FIFO as the new accounting method while a few firms chose the weighted-average method. 
In assessing the impact of abolishing LIFO, we look at several measures of liquidity: 1) working capital, 2) cash and short-term investments, and 3) cash flow from operations. Since these measures fluctuate routinely from year to year, we chose to calculate the five-year average (2007 to 2011) for each of these measures. Since the simple average can be skewed by outliers, we calculated both the five-year simple average and the five-year median. We estimated the total taxes due as $35 \%$ of the company's LIFO reserve. We then compared each measure of liquidity to the each company's estimated taxes, as reported in Table 1.

Table 1: LIFO Taxes as a Percentage of the Liquidity Metric

\begin{tabular}{|l|c|c|c|}
\hline & $\begin{array}{c}\text { 5-year Average } \\
\text { Working Capital }\end{array}$ & $\begin{array}{c}\text { 5-year Average Cash and Short- } \\
\text { Term Investments }\end{array}$ & $\begin{array}{c}\text { 5-Year Average Operating } \\
\text { Cash Flows }\end{array}$ \\
\hline Simple Average & $11.3 \%$ & $28.9 \%$ & $21.5 \%$ \\
\hline Median & $3.9 \%$ & $9.1 \%$ & $7.7 \%$ \\
\hline
\end{tabular}

\section{Working Capital}

Working capital (current assets minus current liabilities) is a fundamental measure of a firm's short-term liquidity. Companies with significant working capital may be able to pay the LIFO tax without straining their financial health. This metric provides a sense of the amount of excess assets that might be used to pay for the LIFO tax burden. To better estimate a company's ability to pay, our study calculated the five year average of working capital. If fewer than five years of data were available, we calculated the average for the shorter term. Companies reporting unclassified balance sheets were not utilized for this particular factor. In respect to a company's working capital, the median LIFO tax burden was 3.9\%.

\section{Cash and Short-Term Investments}

A more stringent metric of ability to pay the LIFO liquidation tax is the average amount of cash and shortterm investments. We compared the amount of each company's cash and short-term investments to $35 \%$ of its LIFO reserve. Four companies with insignificant amounts of cash and short-term investments were removed from this analysis, as they inappropriately skewed the average. Under this metric, the LIFO repeal tax was a median of $9.1 \%$ of cash and short-term investments.

\section{Cash Flow from Operations}

Cash flow from operations is a measure of a company's ability to finance its own operations. Operating cash flow can be reinvested into a company's present operations, invested for future projects, used to pay down debt, and/or distributed to stakeholders. Cash that is not reinvested into operations might be utilized to pay the LIFO tax. Our study found that the median LIFO tax burden was $7.7 \%$ of the five-year average operating cash flow.

Clearly, paying the LIFO liquidation taxes has a significant impact on each of the three measures of liquidity. Comparing the simple average to the median indicates the variability across firms. Some will be greatly affected and some much less affected. Eliminating LIFO inventory accounting will reduce overall liquidity over the next few years although the average impact appears to be moderate.

\section{Absolute Firm Size and the Use of LIFO}

Our study next looked at the connection between firm size and using LIFO. Grouping the 4,206 U.S. domestic, non-financial firms of our study into thirds can be employed to see how frequently small, medium and large firms use LIFO. The results are displayed in Table 2. 
Table 2: Number of LIFO Firms and Total LIFO Reserves by Firm Size

\begin{tabular}{|l|c|c|c|}
\hline \multicolumn{1}{|c|}{ Top, Middle, and Bottom Thirds } & $\begin{array}{c}\text { Number of } \\
\text { Firms }\end{array}$ & $\begin{array}{c}\text { Number of LIFO } \\
\text { Firms }\end{array}$ & $\begin{array}{c}\text { Total LIFO Reserves } \\
\text { (millions) }\end{array}$ \\
\hline $\begin{array}{l}\text { Large firms } \\
\text { Top third } \\
\text { Assets }>\$ 942.71 \mathrm{M}\end{array}$ & 1,402 & 203 & $\$ 98,309.1$ \\
\hline $\begin{array}{l}\text { Medium firms } \\
\text { Middle third } \\
\text { Assets }>\$ 71.85 \mathrm{M} \text { and } \leq \$ 942.71 \mathrm{M}\end{array}$ & 1,402 & 86 & $\$ 2,128.9$ \\
\hline $\begin{array}{l}\text { Small firms } \\
\text { Bottom third } \\
\text { Assets } \leq \$ 71.85 \mathrm{M}\end{array}$ & 1,402 & 9 & $\$ 24.5$ \\
\hline Totals & 4,206 & 298 & $\$ 100,462.5$ \\
\hline
\end{tabular}

As Table 2 makes clear, smaller firms with total assets of less than $\$ 71.85$ million use LIFO far less frequently and the dollar amount of their LIFO reserves is quite small in comparison to medium and large firms. In contrast, the largest firms in the top third of the table are 20 times more likely to employ LIFO and the dollar amount of their LIFO reserves is 400 times larger than that of the small firms. Though simply descriptive, Table 2 clearly indicates that firm size and the use of LIFO are connected.

\section{Rank Order Size of LIFO Firms}

To delve further into this issue, we explored the ten 4-digit industries containing the greatest number firms according to the 2011 Compustat data. For each industry, we calculated the average and median amounts of total assets per firm for both LIFO and non-LIFO firms. The simple average was skewed by the larger and/or smaller firms within a single industry, so we chose to employ the median amount assets to answer this question. The results are presented in Table 3.

Table 3: Top Ten Industries by Number of Firms

\begin{tabular}{|l|l|c|c|c|c|c|}
\hline $\begin{array}{c}\text { SIC } \\
\text { code }\end{array}$ & \multicolumn{1}{|c|}{ Industry } & $\begin{array}{c}\text { Number } \\
\text { of firms }\end{array}$ & $\begin{array}{c}\text { Number } \\
\text { of LIFO } \\
\text { firms }\end{array}$ & $\begin{array}{c}\text { Median } \\
\text { assets LIFO } \\
\text { firms } \\
\text { (millions) }\end{array}$ & $\begin{array}{c}\text { Median } \\
\text { assets non- } \\
\text { LIFO firms } \\
\text { (millions) }\end{array}$ & $\begin{array}{c}\text { LIFO / } \\
\text { non-LIFO } \\
\text { median }\end{array}$ \\
\hline 1311 & Crude petroleum \& natural gas & 191 & 3 & $\$ 60,044.0$ & $\$ 290.9$ & 206.4 \\
\hline 2836 & Biological products, & 183 & 1 & $\$ 3,281.0$ & $\$ 42.9$ & 76.5 \\
\hline 2834 & Pharmaceutical preparations & 172 & 2 & $\$ 69,393.9$ & $\$ 45.3$ & $1,531.9$ \\
\hline 3714 & Motor vehicle parts \& accessories & 42 & 2 & $\$ 3,162.6$ & $\$ 428.4$ & 7.4 \\
\hline 3663 & $\begin{array}{l}\text { Radio \& TV broadcasting \& } \\
\text { communications equipment }\end{array}$ & 41 & 1 & $\$ 1,826.1$ & $\$ 106.1$ & 17.2 \\
\hline 1040 & Gold and silver ores & 39 & 1 & $\$ 1,129.8$ & $\$ 3.0$ & 376.6 \\
\hline 1000 & Metal mining & 32 & 1 & $\$ 14,541.7$ & $\$ 3.3$ & $4,406.6$ \\
\hline 3842 & $\begin{array}{l}\text { Orthopedic, prosthetic \& surgical } \\
\text { appliances \& supplies }\end{array}$ & 30 & 3 & $\$ 1,115.1$ & $\$ 101.4$ & 11.0 \\
\hline 2860 & Industrial organic chemicals & 27 & 5 & $\$ 1,191.7$ & $\$ 309.8$ & 3.8 \\
\hline 3679 & Electronic components, nec & 27 & 1 & $\$ 626.3$ & $\$ 46.3$ & 13.5 \\
\hline
\end{tabular}

*Not elsewhere classified

Table 3 provides several meaningful insights. First, LIFO is often not chosen by the majority of firms within an industry. For example, only one of the 183 firms in SIC code 2836 employed LIFO. In half of the ten industries depicted above, one firm used LIFO. Secondly, the median asset size for LIFO firms is generally much larger than that for non-LIFO firms. The last column in Table 2 shows the relative proportion of the LIFO median to the non-LIFO median of total assets. In every industry, the LIFO median is larger. Often, the LIFO amount is tens and hundreds of times larger. So again, there is compelling evidence that the larger firms within the same industry employ LIFO. 
Having examined industries where most firms did not use LIFO, we then identified industries where LIFO was used by a significant proportion of firms. We focused our attention on industries with 8 or more firms where LIFO was used by $30 \%$ to $70 \%$ of the firms. This yielded the 13 industries shown in Table 4 .

Table 4: Industries with Significant Use of LIFO and 8 or more Firms

\begin{tabular}{|l|l|c|c|c|c|c|}
\hline $\begin{array}{c}\text { SIC } \\
\text { code }\end{array}$ & \multicolumn{1}{|c|}{ Industry } & $\begin{array}{c}\text { Number } \\
\text { of Firms }\end{array}$ & $\begin{array}{c}\text { Number } \\
\text { of LIFO } \\
\text { firms }\end{array}$ & $\begin{array}{c}\text { Median } \\
\text { assets LIFO } \\
\text { firms }\end{array}$ & $\begin{array}{c}\text { Median } \\
\text { assets non- } \\
\text { LIFO firms }\end{array}$ & $\begin{array}{c}\text { LIFO / } \\
\text { non-LIFO } \\
\text { median }\end{array}$ \\
\hline 2510 & Household furniture & 9 & 4 & $\$ 379.1$ & $\$ 262.7$ & 1.4 \\
\hline 2621 & Paper mills & 12 & 5 & $\$ 1,136.9$ & $\$ 1,444.4$ & .8 \\
\hline 2711 & $\begin{array}{l}\text { Newspapers: publishing or publishing \& } \\
\text { printing }\end{array}$ & 8 & 3 & $\$ 1,158.2$ & $\$ 510.8$ & 2.3 \\
\hline 2842 & $\begin{array}{l}\text { Specialty cleaning, polishing and } \\
\text { sanitation preparations }\end{array}$ & 9 & 3 & $\$ 4,163.0$ & $\$ 23.7$ & 175.7 \\
\hline 2911 & Petroleum refining & 23 & 16 & $10,103.3$ & 670.6 & 15.1 \\
\hline 3140 & Footwear, (no rubber) & 9 & 3 & $\$ 851.7$ & $\$ 196.8$ & 4.3 \\
\hline 3312 & $\begin{array}{l}\text { Steel works, blast furnaces \& rolling } \\
\text { mills (coke ovens) }\end{array}$ & 15 & 6 & $\$ 5,248.4$ & $\$ 361.7$ & 14.5 \\
\hline 3420 & Cutlery, handtools \& general hardware & 11 & 4 & $\$ 1,950.0$ & $\$ 141.5$ & 13.8 \\
\hline 3510 & Engines \& turbines & 12 & 4 & $\$ 2,641.6$ & $\$ 84.8$ & 31.2 \\
\hline 3560 & $\begin{array}{l}\text { General industrial machinery \& } \\
\text { equipment }\end{array}$ & 8 & 5 & $\$ 1,632.3$ & $\$ 18.2$ & 89.7 \\
\hline 3585 & $\begin{array}{l}\text { Air-cond. \& warm air heatg. equip. \& } \\
\text { comm. \& indl. refrig. equip. }\end{array}$ & 8 & 4 & $\$ 953.1$ & $\$ 519.3$ & 1.8 \\
\hline 5051 & $\begin{array}{l}\text { Wholesale-metals service centers \& } \\
\text { offices }\end{array}$ & 13 & 7 & $\$ 2,058.4$ & $\$ 629.3$ & 15.1 \\
\hline 5122 & $\begin{array}{l}\text { Wholesale-drugs, proprietaries \& } \\
\text { druggists' sundries }\end{array}$ & 10 & 3 & $\$ 22,845.9$ & $\$ 212.6$ & 107.5 \\
\hline
\end{tabular}

Table 4 shows that the median LIFO firm is generally larger than the non-LIFO firm in industries where the use of LIFO is common. This held true in all but SIC code 2621. The multiples in the last column are not are big as they were in Table 3 but they still strongly suggest a connection between firm size and the use of LIFO. In over half of the above industries, the median LIFO firm was more than 10 times larger than the non-LIFO firm.

Finally, since many industries in our study contained only one LIFO firm, we wondered if an analysis of those industries would shed more light on the issue of firm size and the use of LIFO. We therefore calculated the percentile size ranking of the LIFO firm in each such industry. The results are presented in Table 5. 
Table 5: Industries with Only One LIFO Firm and 10 or more Firms

\begin{tabular}{|c|c|c|c|c|c|}
\hline $\begin{array}{l}\text { SIC } \\
\text { code }\end{array}$ & Industry & $\begin{array}{l}\text { Number } \\
\text { of Firms }\end{array}$ & $\begin{array}{c}\text { Number } \\
\text { of LIFO } \\
\text { Firms }\end{array}$ & $\begin{array}{c}\text { LIFO Firm's } \\
\text { Percentile } \\
\text { Ranking }\end{array}$ & $\begin{array}{c}\text { LIFO Firm's } \\
\text { Ordinal } \\
\text { Rank }\end{array}$ \\
\hline 2836 & Biological products, (no diagnostic substances) & 183 & 1 & $3.28 \%$ & 6 \\
\hline 3663 & Radio \& TV broadcasting \& communications equipment & 41 & 1 & $19.51 \%$ & 8 \\
\hline 1040 & Gold and silver ores & 39 & 1 & $7.69 \%$ & 3 \\
\hline 1000 & Metal mining & 32 & 1 & $6.25 \%$ & 2 \\
\hline 3679 & Electronic components, nec* & 27 & 1 & $14.81 \%$ & 4 \\
\hline 3559 & Special industry machinery, nec* & 24 & 1 & $8.33 \%$ & 2 \\
\hline 2300 & $\begin{array}{l}\text { Apparel \& other finished products of fabrics \& similar } \\
\text { material }\end{array}$ & 23 & 1 & $47.83 \%$ & 11 \\
\hline 3826 & Laboratory analytical instruments & 18 & 1 & $5.56 \%$ & 1 \\
\hline 1220 & Bituminous coal \& lignite mining & 17 & 1 & $11.76 \%$ & 2 \\
\hline 2086 & Bottled \& canned soft drinks \& carbonated waters & 16 & 1 & $6.25 \%$ & 1 \\
\hline 1389 & Oil \& gas field services, nec* & 15 & 1 & $6.67 \%$ & 1 \\
\hline 1400 & Mining \& quarrying of nonmetallic minerals (no fuels) & 15 & 1 & $6.67 \%$ & 1 \\
\hline 3651 & Household audio \& video equipment & 15 & 1 & $40.00 \%$ & 6 \\
\hline 2844 & Perfumes, cosmetics \& other toilet preparations & 14 & 1 & $7.14 \%$ & 1 \\
\hline 3620 & Electrical industrial apparatus & 14 & 1 & $64.29 \%$ & 9 \\
\hline 3823 & $\begin{array}{l}\text { Industrial instruments for measurement, display, and } \\
\text { control }\end{array}$ & 14 & 1 & $21.43 \%$ & 3 \\
\hline 4991 & Cogeneration services \& small power producers & 14 & 1 & $7.14 \%$ & 1 \\
\hline 2090 & Miscellaneous food preparations \& kindred products & 13 & 1 & $30.77 \%$ & 4 \\
\hline 2030 & $\begin{array}{l}\text { Canned, frozen \& preserved. fruit, vegetable \& food } \\
\text { specialties }\end{array}$ & 12 & 1 & $33.33 \%$ & 4 \\
\hline 3621 & Motors \& generators & 12 & 1 & $8.33 \%$ & 1 \\
\hline 5940 & Retail-miscellaneous shopping goods stores & 11 & 1 & $81.82 \%$ & 9 \\
\hline 3569 & General industrial machinery \& equipment, nec & 10 & 1 & $20.00 \%$ & 2 \\
\hline 4610 & Pipe lines (no natural gas) & 10 & 1 & $20.00 \%$ & 2 \\
\hline
\end{tabular}

*Not elsewhere classified

Table 5 clearly shows that LIFO firms tend to be among the largest in their respective industry. In seven of the 23 industries represented, the LIFO firm ranked the largest. In 17 of the 23, the LIFO firms ranked as one of the top four firms. Note that each of these industries consisted of 10 or more firms. Thus, the LIFO firm was clearly among the largest in its respective industry.

\section{CONCLUSION}

This study shows that the aggregate LIFO reserve of publicly-traded firms and the number of firms utilizing LIFO has been fairly stable over most of the past twenty years. Only during the past five years has the dollar amount of LIFO reserves grown dramatically. Despite the recent growth in reserves, the number of firms employing LIFO has actually declined during this period.

This study also quantified the impact on firms from repealing LIFO. We calculated the five-year simple average and median measures for working capital, cash and short-term investments, and cash flow from operations. We then compared the estimated tax burden from repealing LIFO with each of these liquidity measures. Our study determined that impact on liquidity will be significant but might be characterized as 'manageable.' We simply looked at the total tax obligation computed using a maximum tax rate of $35 \%$ but the actual proposals call payments of LIFO-related taxes over an extended period of time.

By examining the nexus of LIFO usage, absolute firm size, and relative firm size, this study documented a strong propensity for large firms to use LIFO. Our study found that large firms were more than twice as likely to use LIFO as medium size firms. Similarly, the large firms in our study were over 20 times as likely as small firms to use LIFO. Likewise, larger companies in individual industries tended to use LIFO more often than smaller companies. 
Moreover, our study found that companies utilizing LIFO ranked near the top of their industry in terms of size, often ranking in the top four firms of the industry.

This study was limited in scope to publicly-traded firms and thus its results may not be applicable to private companies. However, if the relationship between firm size and the use of LIFO applies to both public and private companies, then several observations follow. Private companies are generally smaller than public companies. To the extent that smaller firms are less inclined to use LIFO, then it may be the case the LIFO is generally not attractive to private companies. This observation runs counter to claims from trade associations and may call into question the potential deficit reduction of repealing LIFO. Of course, this observation is conditioned on the assumption that the documented connection between firm size and the use of LIFO by public companies also exists for private firms. That question is open for future study.

\section{AUTHOR INFORMATION}

John Kostolansky received a M.S. and Ph.D in Economics from Columbia University. He is an Associate Professor of Accounting at Loyola University Chicago and has served as Chairman of the Accounting Department and as Associate Dean of the Graduate School of Business. His research interests are in the areas of financial statement analysis, issues in financial reporting, and pension accounting. His publications have appeared in the Journal of Accounting, Auditing, and Finance, Journal of Commercial Bank Lending, Journal of Economic Asymmetries, Journal of Applied Business Research, and the Journal of Business Case Studies. E-mail: jkostol@luc.edu (Corresponding author)

Ethan Polnaszek received a B.B.A. and M.S. in Accountancy from Loyola University Chicago. Over the past five years, he has held various positions at Oshkosh Defense, Pierce, and Raytheon Missile Systems and he will begin his public accounting career at Deloitte \& Touche in September 2013. His research interests are in the areas of financial statement analysis, governmental budgeting, and the defense aerospace industry. This is his first publication.

\section{REFERENCES}

1. Financial Accounting Standards Board at www.fasb.org/news/memorandum.pdf

2. Kleinbard, E., Plesko, G., and Goodman, C. 2006. Is It Time to Liquidate LIFO?" Tax Notes Vol. 113, No. 3: 237-253.

3. Kostolansky, J. 2009. The Impact of LIFO in the Fortune 500 in 2007. The Journal of Applied Business Research, Vol. 9, No. 9: 29-35.

4. The LIFO Coalition. 2010. Reasons Why the LIFO Method Should Not Be Repealed in the Context of Business Tax Reform at http://waysandmeans.house.gov/uploadedfiles/lifo_coalition_71912fc.pdf

5. Mulford, C. and Comiskey, E. 2008. The Potential Consequences of the Elimination of LIFO as a Part of IFRS Convergence. Working Paper, Georgia Tech Financial Analysis Lab at www.mgt.gatech.edu/finlab

6. Pear, R. July 12, 2011. Lobbyists Rush to Defend Tax Rule on Inventory and Profits. The New York Times.

7. U.S. Budget for FY 2014, p. 261 at http://www.gpo.gov/fdsys/pkg/BUDGET-2014-BUD/pdf/BUDGET2014-BUD.pdf

8. Vitale, E. 2010. A Descriptive Analysis of the Impact of LIFO Repeal. Boston College Honors Thesis.

9. Weild, D. and Kim, E. 2009. A Wake-up Call for America. Grant Thornton. 
NOTES 